\title{
STUDI FENOMENOLOGI: PENGALAMAN PETUGAS KEPOLISIAN DALAM MEMBERIKAN TINDAKAN PERTOLONGAN PERTAMA KORBAN KECELAKAAN LALU LINTAS
}

\author{
Ikhda Ulya* ${ }^{*}$, Retty Ratnawati** Kumboyono*
}

\begin{abstract}
Abstrak
Petugas kepolisian memegang peranan sangat penting dalam memberikan pertolongan pertama kepada korban kecelakaan jika terdapat keterbatasan petugas medis untuk memberikan pertolongan. Tentunya polisi memiliki pengalaman tersendiri yang perlu digali untuk mengetahui tindakan pertolongan pertama apa saja yang selama ini dilakukan ketika menolong korban kecelakaan selain tugas utamanya sebagai polisi. Penelitian ini menggunakan desain kualitatif fenomenologi hermeneutic untuk mengeksplorasi dan menginterpretasikan makna pengalaman petugas kepolisian dalam memberikan tindakan pertolongan pertama pada korban kecelakaan lalu lintas. Jumlah partisipan sebanyak 5 orang yang bertugas di Pos Lantas Purwodadi Wilayah Polres Pasuruan. Instrumen dalam penelitian ini yaitu peneliti sebagai instrumen inti dan alat penunjang lainnya yaitu berupa netbook yang dilengkapi dengan program perekam suara (camtasia studio), bolpoin, dan kertas untuk field note. Data dikumpulkan melalu in depth interview diolah menjadi tranksrip dan kemudian dianalisis dengan menggunakan metode Dikelmann et al. Hasil penelitian didapatkan dua tema besar yaitu segera menolong sesuai dengan kemampuan dan peralatan yang ada serta menolong dengan cara apapun demi keselamatan korban. Kesimpulannya yaitu polisi berusaha semaksimal mungkin sesuai dengan kemampuan yang dimiliki dalam memberikan tindakan pertolongan pertama pada korban kecelakaan demi keselamatan korban. Oleh karena itu, perlu adanya peningkatan kemampuan polisi dalam memberikan tindakan pertolongan pertama untuk meningkatkan angka keselamatan korban kecelakaan ditengah keterbatasan pelayanan medis di luar rumah sakit.
\end{abstract}

Kata kunci : kecelakaan lalu lintas, pertolongan pertama, polisi

\section{PHENOMENOLOGICAL STUDY: THE POLICE EXPERIENCE ON PROVISION OF FIRST AID FOR TRAFFIC CRASH VICTIMS}

\begin{abstract}
Police officer holds a very important role in giving first aid to the traffic crash victim if there are limitations of medical officer to provide help. They certainly have special experience in giving first aid to traffic crash victims besides their main duties as police officer. This research was used qualitative phenomenological hermeneutic design to explore and to elucidate in-depth about the experience of police officers in providing first aid for traffic crash victims. There are 5 participants who served in Purwodadi police station district of Pasuruan. This study Instruments are including researcher as core instruments and netbook with voice recording application (camtasia studio), ballpoint, and paper. Data collected through a comprehensive interview and processed into transcript then analyzed using Dikelmann et al. method. The research results obtained by two major themes, the police officer give immediate help to the victims with their ability and minimum equipment, secondly they help in any way to save the victim. The conclusion is that the police officer to provide help to the victims to save their lives. Therefore, it is necessary to improve the ability of the police in providing first aid in order to increase the safety in the midst of limited medical services outside the hospital.
\end{abstract}

Keywords: first aid, police, traffic accident

*Jurusan Keperawatan, FK UB

** Laboratorium Fisiologi, FK UB

E-mail: ikhda.fk@ub.ac.id 


\section{Pendahuluan}

Kecelakaan lalu lintas merupakan masalah yang serius dalam kehidupan masyarakat, baik di dalam negeri maupun di luar negeri. Di negara berkembang, total korban lebih dari $85 \%$ mengalami kematian dan $90 \%$ mengalami kecacatan. Dari tahun 1983 sampai 1992 angka mortalitas akibat kecelakaan lalu lintas meningkat dari $13 \%$ menjadi $18 \%$ di negara berkembang. Peningkatan jumlah kejadian kecelakaan lalu lintas ini sebagai konsekuensi dari peningkatan penggunaan kendaraan bermotor. ${ }^{1}$ Indonesia merupakan salah satu negara yang memiliki tingkat kecelakaan lalu lintas cukup tinggi. Dalam kurun waktu sepuluh tahun angka kematian akibat kecelakaan di Indonesia nilainya mengalami peningkatan dua kali lipat. ${ }^{2}$ Data Kepolisian RI tahun 2009 menyebutkan, sepanjang tahun tersebut terjadi sedikitnya 57.726 kasus kecelakaan di jalan raya. Artinya, dalam setiap 9,1 menit sekali terjadi satu kasus kecelakaan. ${ }^{4}$ Angka kematian akibat kecelakaan di Indonesia pada kurun waktu tahun 2000-2010 terus mengalami peningkatan, rata-rata perkiraan kematian akibat kecelakaan tiap tahunnya adalah 13.362. ${ }^{2}$

Banyaknya korban akibat kecelakaan transportasi (lalu lintas) yang menimbulkan kondisi gawat darurat, membutuhkan pertolongan secara cepat pada lokasi kejadian untuk mencegah morbiditas dan mortalitas korban. Pertolongan yang diberikan di lokasi kejadian merupakan bagian dari prehospital care. Prehospital care ini diberikan kepada korban sebelum korban kecelakaan lalu lintas sampai di rumah sakit. ${ }^{5}$ Pemberian pertolongan prehospital care secara tepat dapat menurunkan risiko kematian akibat trauma. ${ }^{6}$ Di Indonesia, terdapat jutaan jumlah pasien gawat darurat akibat kecelakaan yang meninggal dunia. Dari jumlah tersebut, $50 \%$ di antaranya kematian dapat dicegah. Berdasarkan data pada tahun 2006, di Jakarta terdapat 81 korban kecelakaan pada usia muda dalam kondisi hidup ketika polisi tiba di tempat kejadian, kemudian korban dapat meninggal dunia saat perjalanan menuju rumah sakit. ${ }^{2}$

Di negara berkembang, misalnya di Indonesia, pelayanan prehospital care masih sangat kurang dan masih jauh dari standar yang ada di negara barat, sehingga WHO terus mengembangkan program penanganan gawat darurat yang berbasis pada masyarakat sebagai lay person yang bertindak menjadi first responder terhadap kejadian kegawatan sehari-hari. ${ }^{3} \quad \mathrm{Hal}$ tersebut memungkinkan negara berkembang untuk memberikan layanan kegawat daruratan kepada warganya dengan optimum. Pertolongan secara cepat dan tepat terhadap korban kecelakaan lalu lintas terutama dengan kondisi kegawatan sangat dibutuhkan, karena hal tersebut dapat mencegah keparahan kondisi korban. ${ }^{5}$ Tentunya, pertolongan secara cepat dan tepat juga dilakukan oleh seorang yang berkompeten, dalam hal ini petugas medis. Namun, fenomena yang dapat diamati di masyarakat ketika sebuah kecelakaan lalu lintas terjadi, maka yang memberikan pertolongan pertama (first responder) adalah sebagian besar bukan petugas medis, akan tetapi orang awam yang berada di sekitar lokasi kejadian.

First responder yang sering dijumpai dan bertindak memberikan pertolongan adalah petugas kepolisian yang mengamankan kejadian kecelakaan lalu lintas atau masyarakat yang sedang di sekitar lokasi kejadian. Karena pada kenyataannya ketika terjadi sebuah kecelakaan lalu lintas, maka yang datang ke lokasi kejadian terlebih dahulu adalah petugas kepolisian, kemudian disusul 
kedatangan ambulans. Bahkan tidak jarang pula, petugas kepolisian yang mengantar korban kecelakaan ke rumah sakit untuk mendapatkan pertolongan.

Hasil studi pendahuluan melalui wawancara didapatkan data bahwa pemberian pertolongan pertama terhadap korban kecelakaan lalu lintas di wilayah Polres Pasuruan sering tidak dilakukan oleh petugas medis atau orang di sekitar lokasi kejadian sebagai first responder yang berkompeten. Petugas kepolisian bersama warga disekitar lokasi kejadian memberikan pertolongan semampuanya yang penting korban segera tertolong. Respons time ambulans di wilayah Pos Lantas Purwodadi Polres Pasuruan ini memakan waktu lebih lama untuk tiba di lokasi kejadian dibandingkan dengan kedatangan petugas kepolisian yang tiba lebih dahulu. Selain itu juga, kapasitas ambulans gawat darurat terhitung terbatas untuk memberikan pelayanan prehospital bagi korban kecelakaan lalu lintas. Di sisi lain, korban kecelakaan lalu lintas yang merupakan warga negara berhak untuk mendapatkan pelayanan yang optimal. ${ }^{2}$ Jayaraman et al. (2009), menyatakan bahwa petugas kepolisian memegang peranan sangat penting dalam memberikan pertolongan pertama kepada korban kecelakaan jika terdapat keterbatasan petugas medis untuk memberikan pertolongan.

Petugas kepolisian memiliki peran yang penting dalam menolong korban kecelakaan. Petugas kepolisian pasti mempunyai pengalaman yang dapat dieksplorasi karena menjadi penolong pertama bukan hal yang mudah. Menurut data kepolisian kabupaten Pasuruan, di jalan protokol Surabaya Malang sering terjadi kecelakaan yang mengakibakan luka berat atau korban meninggal dunia. Petugas kepolisian di wilayah kabupaten yang terlalui jalan protokol tersebut sering melakukan pertolongan kepada korban kecelakaan lalu lintas dengan luka berat dan terkadang juga menolong korban sendiri dengan bantuan masyarakat tidak didampingi oleh petugas medis. Sehingga, banyak sekali pengalaman yang dapat digali dari petugas kepolisian yang ada di sekitar wilayah Kabupaten Pasuruan yang dilalui jalan protokol. Dalam hal ini, wilayah Pos Lantas Purwodadi Polres Pasuruan.

Petugas kepolisian dalam menghadapi kecelakaan lalu lintas tidak hanya berfokus pada korban kecelakaan saja, akan tetapi juga bertanggung jawab terhadap tugasnya yaitu menjaga keamanan dan ketertiban lalu lintas dan lingkungan sekitar. Namun, masyarakat juga menaruh harapan kepada petugas kepolisian untuk mampu menolong korban kecelakaan lalu lintas.

\section{Bahan dan Metode}

Penelitian ini menggunakan desain kualitatif fenomenologi hermeneutic untuk mengeksplorasi dan menginterpretasikan makna pengalaman petugas kepolisian dalam memberikan tindakan pertolongan pertama pada korban kecelakaan lalu lintas. Penelitian dilakukan pada bulan Juni 2013. Lokasi penelitian ini di Pos Lantas Purwodadi Polres Pasuruan dengan jumlah partisipan sebanyak 5 orang. Pos Lantas Purwodadi dipilih sebagai lokasi penelitian karena hasil studi pendahuluan menunjukkan bahwa petugas di Pos Lantas Purwodadi sering memberikan pertolongan pertama pada korban kecelakaan dengan dengan kategori luka berat. Saturasi data telah tercapai dari 5 partisipan tersebut.

Instrumen dalam penelitian ini yaitu peneliti sebagai instrumen inti dan alat panunjang lainnya yaitu berupa netbook yang dilengkapi dengan program perekam suara camtasia studio, bolpoin, dan kertas untuk field note. Data dikumpulkan melalu indepth interview diolah menjadi transksrip dan kemudian dianalisis dengan 
menggunakan metode Dikelmann et al. (1989) melalui tujuh tahap dalam memahami serta menginterpretasikan data. Proses interview dilakukan sesuai kesepakatan dengan partisipan yaitu pada jam dinas dan partisipan sedang tidak ada panggilan tugas. Penelitian ini telah melalui pertimbangan etik dan kriteria keabsahan data harus dipenuhi dalam penelitian kualitatif.

\section{Hasil}

Hasil penelitian ini didapatkan dua tema yaitu segera menolong sesuai dengan kemampuan dan peralatan yang ada dan menolong dengan cara apapun demi keselamatan korban. Polisi berusaha untuk segera melakukan tindakan sesuai kemampuan yang dimiliki demi menyelamatkan korban. Dua tema besar tersebut dibangun dari beberapa sub tema. Untuk tema segera menolong sesuai dengan kemampuan dan peralatan yang ada terdiri dari dua subtema yaitu kemampuan menolong dan pemberian pertolongan pertama. Subtema yaitu kemampuan menolong dibangun dari empat kategori yaitu kemampuan menolong terbatas, tidak benar sepenuhnya dalam menerapkan cara memberikan pertolongan pertama, pengalaman menghentikan perdarahan kurang, dan tidak bisa menolong. Subtema pemberian pertolongan pertama terdiri dari lima sub-sub tema yaitu triage lapangan, panggil bantuan, membebaskan jalan napas, memasang balut bidai, dan mengangkat korban.

Pada tema menolong dengan cara apapun demi keselamatan korban dibangun dari sub tema perhatian terhadap penggunaan alat pelindung diri saat menolong dan usaha memberikan pertolongan. Subtema perhatian terhadap penggunaan alat pelindung diri saat menolong dari dua sub-sub tema yaitu tidak menggunakan alat pelindung diri saat menolong korban dan jarang menggunakan alat pelindung diri. Pada sub-sub tema tidak menggunakan alat pelindung diri saat menolong korban dibangun dari satu kategori yaitu menyedot dengan mulut yang merupakan tidakan pertolongan yang dilakukan oleh polisi terhadap korban kecelakaan. Sedangkan untuk sub tema jarang menggunakan alat pelindung diri dibangun dari sub-sub tema yaitu jarang memakai handschoen dan memakai kaos tangan karet jika korban luka parah. Sedangkan sub tema usaha memberikan pertolongan dibangun dari beberapa sub-sub tema yaitu pertolongan di lokasi, pemanfaatan alat seadanya, transportasi ke rumah sakit, dan pengambilan keputusan. Sub-sub tema pertolongan di lokasi yang dilakukan oleh polisi yaitu berupaya semaksimal mungkin menolong korban. Sub-sub tema pemanfaatan alat seadanya untuk menolong korban dengan patah tulang yaitu berupa blabak, kardus, dan kayu. Kemudian untuk sub-sub tema transportasi ke rumah sakit meliputi mengantarkan sendiri dengan ambulans, mengantarkan sendiri dengan kendaraan yang ada, serta mengantarkan sendiri dengan kendaraan dinas (pick-up). Sub-sub tema pengambilan keputusan yaitu bertanggungjawab terhadap tindakan operasi yang dilakukan kepada korban kecelakaan mengingat korban butuh segera dioperasi namun belum ada anggota keluarga yang ada di rumah sakit.

\section{Pembahasan}

Segera Menolong Sesuai dengan Kemampuan dan Peralatan yang Ada

Pada tema 1 yaitu segera menolong sesuai dengan kemampuan dan peralatan yang ada dibangun dari dua sub tema yaitu kemampuan menolong dan pemberian pertolongan pertama. Kemampuan dalam menolong akan mempengaruhi jenis pertolongan pertama yang diberikan kepada 
korban kecelakaan. Sub tema kemampuan menolong dibangun oleh empat kategori yaitu kemampuan menolong terbatas, tidak benar sepenuhnya dalam menerapkan cara memberikan pertolongan pertama, pengalaman menghentikan perdarahan kurang, dan tidak bisa menolong.

Kemampuan menolong yang terbatas menyebabkan cara pemberian pertolongan tidak benar sepenuhnya termasuk salah satunya pengalaman menghentikan perdarahan kurang bahkan ada partisipan yang merasa bahwa tidak bisa menolong. Partisipan merasa kemampuan menolong terbatas karena mereka bukan tenaga kesehatan yang dapat melakukan pertolongan pertama dengan benar. Sehingga diusahakan segera membawa ke rumah sakit atau puskesmas.

\section{"Kita kan kemampuannya masing- masing kan terbatas, kan tidak mungkin petugas kesehatan itu melekat pada kita...dari pengalaman kita itu mungkin sangat kurang untuk apa itu memberikan eee pertolongan pada waktu itu pertama waktu kecelakaan itu, makanya secepat mungkin kita bawa ke rumah sakit atau puskesmas terdekat." (P3)}

Polisi dalam memberikan pertolongan pertama kepada korban kecelakaan merasa tidak benar sepenuhnya dalam menerapkan cara memberikan pertolongan pertama karena mereka merasa bukan petugas kesehatan sehingga mereka merasa pertolongan yang diberikan belum benar sepenuhnya. Salah satu tindakan yang belum bisa dilakukan dengan benar yaitu menghentikan perdarahan.

"Kalau perdarahan, kalau emang ada perawatan, mungkin korban untuk menghentikan sementara itu, untuk pengalaman seperti itu saya kira masih kurang...kalau perdarahan itu cepet langsung saya bawa ke rumah sakit atau puskesmas terdekat." (P5)

Pengalaman dalam menghentikan perdaraan yang kurang membuat polisi merasa kurang mampu dalam memberikan pertolongan pertama. Pernyataan partisipan di atas menunjukkan dengan kurangnya pengalaman dalam menghentikan perdarahan, sehingga tidak ada tindakan yang dilakukan ketika terjadi perdarahan. Polisi segera membawa ke rumah sakit untuk mencari pertolongan terhadap perdarahan yang terjadi pada korban. Ada salah satu partisipan yang menyatakan bahwa ketika terjadi kecelakaan maka tidak ada yang dilakukan selain hanya segera membawa ke rumah sakit karena partisipan merasa tidak bisa menolong.

Sub tema pemberian pertolongan pertama terdiri dari lima sub sub tema yaitu triage lapangan, panggil bantuan, membebaskan jalan napas, memasang balut bidai, dan mengangkat korban. Berikut akan dijelaskan mengenai masing-masing subsub tema. Sub-sub tema triage lapangan dibangun dari dua kategori yaitu memeriksa pernapasan dan kemungkinan bisa diselamatkan. Memeriksa pernapasan termasuk salah satu metode dalam triage atau memilah korban kecelakaan untuk menentukan priortas pertolongan.

$$
\begin{aligned}
& \text { "Kita tolong seumpama masih ada } \\
& \text { yang masih hidup sesegera kita bantu } \\
& \text { yang masih hidup kita tolong } \\
& \text { seumpama masih ada yang masih } \\
& \text { hidup sesegera kita bantu yang masih } \\
& \text { hidup." (P2) }
\end{aligned}
$$

Pernyataan partisipan di atas menunjukkan usaha polisi dalam memilah korban kecelakaan jika jumlahnya lebih dari satu untuk memprioritaskan pemberian pertolongan. Metode yang digunakan 
sederhana dengan memeriksa pernapasan. Jika masih bernapas maka didahulukan untuk diberikan pertolongan daripada yang sudah tidak bernapas atau meninggal. Hasil triage yang dilakukan memberikan informasi kepada polisi mengenai kondisi yang memungkinan bisa diselamatkan. Ada kemungkinan bisa diselamatkan menjadi dasar prioritas dalam pemberian pertolongan.

Setelah melakukan triage, tindakan selanjutnya yaitu panggil bantuan. Sub-sub tema panggil bantuan terdiri dari satu kategori yaitu telpon ambulans. Namun, ada beberapa kasus menurut polisi tidak memerlukan pemanggilan ambulans dan dapat diantarkan langsung ke rumah sakit atau puskesmas terdekat. Kegiatan rutin yang dilakukan oleh polisi yaitu memanggil bantuan medis dengan cara telpon ambulans, bahkan polisi langsung menghubungi pengemudi ambulansnya.

“...Suatu saat ada apa-apa kita koordinasi dengan puskesmas terdekat "mas, ini ada kecelakaan, ini membutuhkan ambulans segera..." (P1)

Adapun tindakan yang bisa dilakukan oleh polisi adalah membebaskan jalan napas. Sub-sub tema membebaskan jalan napas terdiri dari dua kategori yaitu mengorek benda di mulut dan menyedot darah. Mengorek benda yang dimulut (finger sweep) adalah salah satu upaya pembebasan jalan napas yang dilakukan oleh partisipan. Tindakan pembebasan jalan napas yang dilakukan lainnya yaitu menyedot darah. Tindakan yang dilakukan tidak aman bagi partisipan karena tidak menggunakan alat pelindung diri.

"...dengan terpaksa saya congkel mie yang ada di mulutnya..."(P1) "...dan darah yang ada di hidung saya sedot." (P1)

Tindakan pertolongan pertama selanjutnya yang dilakukan polisi adalah memasang balut bidai. Sub-sub tema memasang balut bidai terdri dari empat kategori yaitu ditahan dengan kayu, memasang sepalek, menopang, dan meluruskan. Ditahan dengan kayu merupakan metode yang digunakan oleh polisi untuk mengimobilisasi area yang mengalami patah tulang.

"Tangannya yang patah kita tahan dengan itu, soale kalo gak kayak gitu biasanya goyang dikit kesakitan, tambah parah...kalo patah kita biasanya kita nyari blabak dulu juga di mobil juga ada blabak kayak triplek gitu" (P2)

Pernyataan partisipan di atas menunjukkan bahwa tindakan yang dilakukan ketika ada tanda patah tulang pada korban maka ditahan dengan kayu agar tidak kesakitan dan mencegah luka semakin parah. Metode ini juga untuk memudahkan polisi ketika mengangkat korban agar tidak kesakitan. Tindakan lain yang dilakukan oleh polisi ketika ada tanda patah tulang dengan memasang sepalek. Memasang sepalek digunakan untuk mencegah keparahan patah tulang yang terjadi pada korban kecelakaan. Sepalek dapat terbuat dari alat seadanya di lokasi kejadan seperti kayu, sirap, atau kardus yang penting dapat mencegah pergerakan area yang patah. Menopang juga cara yang digunakan oleh polisi untuk mengimobilisasi area yang patah tulang. Sebelum memasang balut bidai, ada kalanya polisi juga pernah melakukan tindakan meluruskan atau reposisi untuk mengembalikan posisi anggota tubuh yang mengalami deformitas 
atau pembengkokan karena cedera dengan meluruskan kembali ke posisi semula.

"Ya biasanya diluruskan dulu kan mbak, kan ada yang patah langsung apa gak seperti lurus seperti biasanya terus kita sama orang-orang tu biasanya langsung diluruskan." (P4)

Sub-sub tema mengangkat korban terdiri dari satu kategori yaitu diangkat bersama-sama. Cara polisi dalam mengangkat korban yaitu dengan diangkat bersama-sama. Cara mengangkat yang dilakukan oleh polisi sebagai upaya untuk mencegah bertambah parahnya luka yang diderita korban. Pernyataan dua partisipan tersbebut menggambarkan cara-cara mengangkat korban kecelakaan yang mengalami cedera. Korban diangkat dengan hati-hati oleh beberapa orang untuk meminimalisir pergerakan area cedera.

“...Kakinya seumpama patah...jadi yang orang satu bawa yang pahanya...jadi untuk tubuhnya diserahkan orang lain." (P2)

\section{Menolong dengan Cara Apapun Demi Keselamatan Korban}

Tema 2 yaitu menolong dengan cara apapun demi keselamatan korban terdiri dari dua sub tema yaitu perhatian terhadap penggunaan alat pelindung diri saat menolong dan usaha untuk menolong. Perhatian terhadap penggunaan alat pelindung diri saat menolong merupakan hal yang sangat penting bagi penolong, karena jika hal ini tidak diperhatikan dapat membahayakan penolong. Perhatian terhadap penggunaan alat pelindung diri saat menolong terdiri dari dua sub-sub tema yaitu tidak menggunakan alat pelindung diri dan jarang menggunakan alat pelindung diri. Salah satu partisipan mengungkapkan bahwa pernah melakukan pertolongan tanpa menggunakan alat pelindung diri yaitu pada saat melakukan tindakan menyedot dengan mulut. Hal ini masuk dalam sub-sub tema tidak menggunakan alat pelindung diri.

$$
\begin{aligned}
& \text { "Mungkin sebelum kecelakaan, dia } \\
& \text { anak tersebut makan mie. Nah, } \\
& \text { akhirnya tersumbat di hidung di mulut. } \\
& \text { Akhirnya dengan mulut saya, saya } \\
& \text { sedot sampek hidungnya saya sedot } \\
& \text { dan jalan atau tujuan jalan napasnya } \\
& \text { itu ndak tersumbat...hanya dipake } \\
& \text { mulut saya mbak, karna apa? Karna } \\
& \text { dalam keadaan darurat kalaupun } \\
& \text { mungkin ada larangan yang saya } \\
& \text { maksud tujuan saya hanyalah satu } \\
& \text { supaya dia itu bisa bernapas..." (P1) }
\end{aligned}
$$

Pernyataan partisipan di atas menunjukkan bahwa untuk mengeluarkan darah yang ada di mulut korban disedot dengan menggunakan mulut tanpa menggunakan alat pelindung apapun yang digunakan. Meski tanpa perlindungan yang dipakai di mulut, polisi tetap menyedot darah korban dengan tujuan hanya satu yaitu membebaskan jalan napas korban agar tidak tersumbat. Alasan partisipan tidak menggunakan alat perlindungan apapun karena dalam kondisi darurat, sehingga hal yang seharusnya tidak boleh dilakukan tetap partisipan lakukan demi menyelamatan korban.

Sub-sub tema selanjutnya yaitu jarang menggunakan alat perlindungan diri saat menolong terdiri dari dua kategori yaitu jarang memakai handschoen dan memakai kaos tangan karet jika korban luka parah. Jarang memakai handschoen oleh petugas kepolisian dan tergantung kasus yang sedang ditangani untuk memutuskan menggunakan handschoen atau tidak. Sebenarnya di tas TPTKP sudah disediakan handschoen untuk menolong korban. Namun itu hanya digunakan jika korbannya mengeluarkan darah dalam jumlah banyak. 
Polisi akan memutuskan memakai kaos tangan karet jika korban terluka parah.

"lya, untuk anu pake handschoen itu, eee kita dibekali handschoen itu di tas TPTKP itu kalo sampai lukanya puarah berdarah-darah itu baru kita pake, kalau hanya sebatas ringan gak mengeluarkan darah itu jarang kita pake..."(P3)

Sub tema usaha memberikan pertolongan terdiri dari empat sub-sub tema yaitu pertolongan di lokasi, pemanfaatan alat seadanya, transportasi ke rumah sakit, dan pengambilan keputusan. Sub-sub tema pertolongan di lokasi terdiri dari satu kategori yaitu berupaya menolong dengan maksimal. Upaya yang dilakukan oleh polisi dalam menolong korban kecelakaan lalu lintas dilakukan dengan maksimal untuk menyelamatkan korban dengan memberikan pertolongan pertama, menyetopkan kendaraan untuk membantu membawa korban ke rumah sakit, kemudian membawanya ke rumah sakit atau puskesmas agar mendapatkan pertolongan medis. Apapun dilakukan oleh polisi demi keselamatan korban. Upaya menolong dengan maksimal diikuti dengan pemanfaatan alat seadanya untuk menolong terdiri dari tiga kategori yaitu blabak, kardus, dan kayu. Blabak merupakan alat seadanya yang digunakan oleh polisi untuk menyangga bagian tubuh yang dicurigai mengalami patah tulang.

"Iya dilakukan tindakan untuk supaya tertolong entah bagaimana caranya...Kalau waktu itu ndak ada yang nolong, kita sudah berupaya menolong, menyetopkan kendaraan, membawa ke puskesmas, sampek kita ndak karu-karuan..." (P1)
“...Kalo patah kita biasanya kita nyari blabak dulu juga di mobil juga ada blabak kayak triplek gitu." (P2)

"Kalau luka berat gimana caranya mungkin dikasih seadanya, mungkin kardus mie atau apa ya diginikan atau mungkin tali apa untuk perban..." (P1)

Kita kalo biasanya pake kayu pake anu, pake kayu sama perban." (P3)

Kayu juga dimanfaatkan oleh partisipan untuk mencegah pergerakan area yang cedera dengan dilengkapi atau dibalut dengan perban yang tersedia di tas TPTKP. Sub-sub selanjutnya yaitu transportasi ke rumah sakit yang terdiri dari tiga kategori yaitu mengantarkan sendiri ke rumah sakit dengan ambulans, mengantarkan sendiri ke rumah sakit dengan kendaraan yang ada, dan mengantarkan sendiri ke rumah sakit dengan kendaraan dinas (pick-up).

“...Bahkan ambulans saya kirim sendiri, saya jejek supaya dia itu cepet sampai di UGD..." (sambil tersenyum) (P1)

Pernyataan partisipan di atas menunjukkan bahwa partisipan ingin segera korban sampai di rumah sakit agar mendapatkan pertolongan medis. Sampai partisipan mengemudikan ambulans sendiri meski sebenarnya ambulans datang juga sudah dielngakapi dengan sopir ambulans. Transportasi dengan ambulans disertai petugas medis yang datang bersama ambulans. Polisi juga mengantarkan sendiri ke rumah sakit dengan kendaraan yang ada. Bisa kendaraan milik warga yang kebetulan melintas dan mau membantu menolong untuk membawa korban ke rumah sakit.

"Eee kalo di sini biasanya eee kalo nunggu ambulans kan terlalu lama, 
mengingat dari ambulans juga terbatas... nunggu kita telpon ke rumah sakit terlalu lama, langsung kita bawa ke rumah sakit pake kendaraan yang ada." (P3)

"...Kalo cuman kecelakaan satu dua biasanya cuman kita sih. Jadi ya mau gak mau kendaraan operasional itu ada pick up, mobil pickup lalu lintas itu, jadi sepertinya kalau kita dilihat itu kurang manusiawi ya, kurang manusiawi, tapi gimana lagi." (P2)

Pernyataan partisipan di atas menunjukkan bahwa sering sekali polisi mengantarkan korban ke rumah sakit dengan menggunakan kendaraan dinas berupa pick-up. Meski dipandang kurang manusiawi namun kendaraan yang tersedia hanya itu mau tidak mau akan digunakan, yang terpenting korban cepat sampai di rumah sakit dan mendapatkan penanganan medis. Sub-sub tema selanjutnya adalah pengambilan keputusan yang terdiri dari satu kategori yaitu bertanggung jawab terhadap tindakan medis. Berikut akan dijelaskan mengenai kategori ini. Bertanggung jawab terhadap tindakan medis merupakan bagian pertolongan terhadap korban kecelakaan dilakukan semaksimal mungkin. Bahkan sebenarnya bukan tugas yang harus dilakukan oleh polisi untuk pertanggungjawaban tindakan medis pun dilakukan demi menyelamatan korban.

"lya kadang-kadang di rumah sakit ndak ada keluarga ndak ada orang tua ndak ada kerabat, sampek-sampek pak ini siapa yang mau operasi siapa yang mau tanggung jawab, kadang-kadang saya sendiri yang meneteskan tanda tangan untuk supaya orang tersebut bisa hidup, nanti kaya apa yang penting orang itu harus hidup ..."

(sambil tersenyum) (P1)

\section{Kesimpulan}

Polisi berusaha semaksimal mungkin sesuai dengan kemampuan yang dimiliki dalam memberikan tindakan pertolongan pertama pada korban kecelakaan demi keselamatan korban.

\section{Daftar Pustaka}

1. Goonewardene $S$, Khalid B, Keith $P$, and Sargeant I. Road Traffic Collisions-Case Fatality Rate, Crash Injury Rate, and Number of Motor Vehicles: Time Trends between A Developed and Developing Coountry. The American Surgeon. 2010; 76(9):77-981.

2. Pusponegoro AD. The Silent Disaster: Bencana dan Korban Massal. Jakarta: Sagung Seto. 2011.

3. Geduld $H$ and Wallis L. Taxi Driver Training in Madagascar: The First Step in Developing A Functioning Prehospital Emergency Care System. Emergency Medicine Journal of Prehospital Care. 2011; 28:794-796.

4. Departemen Perhubungan, Kecelakaan Jalan Raya di Indonesia Terjadi Setiap 9,1 Menit. (Online). 2010. (http://www.dephub.go.id/read/berita/dire ktorat-jenderal-perhu bungan-darat 12307), Diakses 1 April 2013.

5. Elmqvist $C$, Brunt $D$, Fridlund $B$, and Ekebergh M. Being First on the Scene of an Accident-Experiances of "Doing" Prehospital Emergency Care. Journal Compilation Nordic of Caring Science. 2010; 24:266-273.

6. World Health Organization. Prehospital Trauma Care System. Jenewa. 2005.

7. Jayaraman S, Mabweijano JR, Lipnick MS, Caldwell N, Miyamoto J, Wangoda R. et al. Current Patterns of Prehospital Trauma Care in Kampala, Uganda and the Feasibility of A Lay-First-Responder Training Program. World Journal of Surgery. 2009; 33:2512-2521. 